\title{
Understanding Figure of Sunan Kudus as the Internalization of Gusjigang to Develop Entrepreneurship in the Global Competition
}

\author{
Rabith Jihan Amaruli \\ Department of History, Faculty of Humanities \\ Diponegoro University
}

Corresponding Author: rjamaruli@live.undip.ac.id

\begin{abstract}
This article discusses the Gusjigang, cultural values owned among Kudus

Received:

7 December 2017

Accepted:

18 December 2017 people through the understanding figure of Sunan Kudus, the founder of the city. The acronym of Gusjigang is derived from Javanese language, Gus-Ji-Gang, means Bagus (good, capable, or something related to goodness), Ngaji (learning the Qur'an or learn about anything in life), and Dagang (commerce, trade, or everything related to the spirit of business and entrepreneurship). Based on the oral tradition of Kudus people, "already" believed that Gusjigang could not be separated from the figure of Sunan Kudus and the history of the city.
\end{abstract}

Keywords: Gusjigang, Sunan Kudus, internalization.

\section{Introduction}

Internalization simply identified as live on the doctrine, thoughts, values, so the conviction and consciousness manifested in attitude and behavior. The internalization and thoughts needs to be conducted to preserve a certain value, by understanding of history. In the context internalization of Gusjigang, then the understanding of Sunan Kudus becomes the main thing. At least, it is based on two points. First, the doctrine of Gusjigang need to continue to be preserved in order to be lived and practiced by generations. In Kudus, this current condition shows that job vacancy in public and private institutions overrun by hundreds or even thousands of applicants. Whereas formerly, for Kudus people (especially in Kudus Kulon/ West) becoming an employee or worker was something taboo. Second, this understanding aims to provide an answer for some people on historical roots of Gusjigang. This presumption states that gusjigang phenomenon was happened in the early of industrialization era. This article attempts to answer these two questions by the figure of Sunan Kudus.

When we heard about Kudus, there are at least two images of this small town in the north of Java. First, is the town where santri lived with strong socio-religious basis. Second, Kudus is a business town that has socio-economic characteristics. The cigarette industry, paper, electronics, porridge, soup/ soto, batik, and embroidery, will easily bring the people imagination to Kudus. The two typical of Kudus, the 
religious traditions and business (trade) town, can not be escaped from the name of Sunan Kudus. Most people of Kudus strongly believes that the two characteristics tradition is always inherent with Sunan Kudus that was well-known as Islamic preacher, skilled bureaucrat, tenacious trader in Java. Thirdly it is represented in gusjigang thoughts.

The acronym of Gusjigang is derived from Javanese language, Gus-Ji-Gang. The terms of Gus from the word bagus, which means good, capable, or something related to goodness. Furthermore, Ji comes from the word Ngaji, which means learning the Qur'an (in santri's tradition), or learn about anything in life. Then, the terms of Gang from dagang which means commerce or trade, related to the spirit of business, entrepreneurship, accompanied by independent and tenacious. There are no definite historical sources, who and when was gusjigang thoughts appeared. However, the oral tradition of people "already" view that gusjigang could not be separated from the figure of Sunan Kudus. Then, who is the Sunan Kudus? Why is it very important and later become role models for the people of Kudus?

\section{The Figure of Sunan Kudus and the History of Kudus: Historical Basis of Gusjigang}

Before explaining the figure of Sunan Kudus, firstly we should discuss the history of Kudus. Kudus began performing on the stage of history since the 16th century AD (Salam 1995:13). However, does not mean that before that, the area is not known at all and escape from history. Before known as Kudus as it is today, there are two names to refer to this area, namely Loram (Salam 1977: 55) and Sucen (see Budiman 1993:18). Loram name, reminiscent of the sound of inscription in Calcutta which states that formerly King Dharmawangsa, King Airlangga in-law was killed, as a result of the attack King Wura Wari, expressed stormed from Loaram (Poesponegoro and Notosusanto, 1993:174). As has been stated by Rouffaer, Loaram be split into two parts, namely the "loa" and "ram". The word "loa" is derived from the word "lwah", a Javanese ancient term to mention the river, while the word "ram" is synonymous with the word in Sanskrit which means good or captivating (Budiman 1993: 11). This sense fits the geography of Loram in Kudus district, which has a nice river and captivating, namely Kali Gelis (Budiman 1993: 12).

Sucen reminds us of the character of Rara Sucian or Dyah Kili Suci which is embedded on the title of the oldest daughter of King Airlangga named Sri Sanggramawijaya Dharmmaprasadottunggadewi (Mulyana, 2005: 36). It mention that King Airlangga had five sons (Olthof, 1941: 12). The first daughter of King Airlangga was held palace as "rakryan Mahamantri i hino" (princes). That position was the highest in the governance of Airlangga's kingdom, after the King Airlangga passed away. She served in this position from the year 943 to 959 Saka or from 1021 to $1037 \mathrm{AD}$ as a successor of her brother, Sri Sumarawijaya Dharmmasuparnnawahana Tguh Uttunggadewa (Poesponegoro and Notosusanto 1993: 184).

She called by the name of Rara Sucian or Dyah Rara Kili Suci. In the ancient Javanese language, "dyah" is a word that means plural, both for men and women, 
the word "kili" means ascetic women or nuns (Prawiroatmojo 1957: 247), while the word "suci" which means kudus or sacred, is used to denote a place where leaders concerned reside (Prawiroatmojo 1957: 212), namely in the area of the Kudus, precisely in the Kudus. Recently, there can be found a place called Sucen, it is located not far from the famous Kudus Minaret (Budiman 1993: 18).

Dyah Kili Suci chose this area to be imprisoned and to live as nuns. Mentioned, at 966 Saka or 1044 AD the war was broke out between King Panjalu, Sri Maharaja Samarawijaya Dharmmasuparnawahana Tguh Utunggadewa with King Jenggala, Sri Maharaja Mapanji Garasakan. The power-sharing situation was not going well among the children of King Airlangga, make Rara Sucian steady to choose a life imprisoned at once to avoid power. Finally, Rara Sucian was settled in the "Kudus", she spent life in religious Hindu area, until the end of his life. The location of Rara Sucian's residence became known as Sucen. She was later buried in the temple complex of Sri Sangramawijaya or complex of whose known recently as Kudus Minaret (Budiman, 1993:18). In addition to the name of Sucen still found in Kudus district, a sign to corroborate this opinion is the discovery of Jenggalan village as the name of a place in the Kudus and became the district of the Kudus. The name of Jenggalan becomes historical witness the people of Jenggala Kingdom in Kudus.

The name of Kudus given by Sunan Kudus (Shaykh Ja'far Al-Shadiq) after he move from Demak. It is Javanization from $A l-Q u d s$, which is derived from the name, Sucen (holy/ Kudus) (de Graaf and Pigeaud 2001: 111). Sunan Kudus then decided to give a name to the new mosque built in the temple complex of tombs Sri Sanggramawijaya, Mosque Al-Aqsa, the name of the famous mosque in Jerusalem, a Palestinian who is also known as Baitul Maqdis (Budiman 1993: 45). Western visitors has been described of the beauty giant tower since the 17th century, it's architecture identically with the Hindu temples of pre-Islamic era. Sunan Kudus and his followers did not destroy everything that reminiscent the days of pre-Islamic Hindu (de Graaf and Pigeaud 2001: 112).

Sunan Kudus was inspired the development of the region by Baitul Maqdis in Palestine. He also gave the name of a mountain in that region by the name of Mount Muria. Muria reminds us of the name of Mount Moriah in Jerusalem. Muria is the new name given by Sunan Kudus. It is because until the 13th century the name of Muria unknown. Mount Moriah is called by the name of Pau-lau-an, which means mountain located on the rocks. Apparently, Pau-lau-an is verbastering (changing) of Wlahulu (Welahulu), the name of Mount Muria in the Hindus era. Welahulu derived from the word Wlah (Welah), it means split and Hulu means head. Literally, the name Welahulu means "split head". This sense match with the peak of Mount Moria that looks split from afar (Budiman, 1993:47). In the days of Islam, there was a mosque named Mosque Omar which located on the hill of Moriah (Jerusalem). Moriah then transformed into Muria in the local dialect, while on Mount Muria also stand a mosque built by Sunan Muria. He was another Islamic preacher that have important role in socio-religious life of the Kudus society (Salam 1977:50). As well as Sunan Kudus, Sunan Muria's tomb located on Mount Muria. Recently it is visited by 
hundred pilgrims. No wonder, Denys Lombard said that Sunan Muria's tomb is one of the shrinest tombs in Java (Lombard 2007: 267-374).

Back to the figure of Sunan Kudus, according to H.J. De Graaf and Th. Pigeaud, Sunan Kudus (Ja'far Sadiq) is one of the imam of the kingdom of Demak. It is noted that the mosque Demak had five priests (imam), two of whom were Penghulu Rahmatullah from Undung (often known as Sunan Ngudung) and Sunan Kudus. Sunan Ngudung was the father of Sunan Kudus. In Hikayat Hasanuddin stated that father and son were known as religious scholar and propagator of Islamic persistent. Both of them have been involved in the struggle to overthrow the rest of the kingdom of Majapahit, and Sunan Ngudung died as a martyr in the battle. Penghulu Rahmatullah set as the fourth imam of Demak Mosque during Sultan Trenggana, while Sunan Kudus was the fifth imam in Demak Mosque at the end of the era of Sultan Trenggana and at the beginning of Sunan Prawata. Sunan Kudus moved out from Demak to Kudus, after disagreements with the Sultan Demak in determining the date of the beginning of the fasting month (Budiman 1993: 108). Another story tells that the move of Sunan Kudus caused by the presence of Sunan Kalijaga to Demak from Cirebon as the request of Sultan Demak, Sultan Trenggana (Budiman, 109-110). In addition, there was also the possibility of Sunan Kudus to leave Demak, because of his desire to live in freedom and devoted among his entire life. It was aims to deepen knowledge of divinity and do the works of God-sanctioned, outside the court of Demak (Budiman 1993: 110).

The birth of the Kudus can be referenced through the inscription above the mihrab of Mosque Al-Aqsa in the form of candra sengkala lamba, it written in Arabic. The complete inscription reads as follows:

"Bismillaahirrahmaanirrahiim. Aqaama bina-al masjid al-Aqsha wal balad al-Kuds Khaliifatu haadzad dahr habru (aali) Muhammad, yasytari . . . izzan fi jannah al-khuldi . . qurban minarrahman bibalad al-Kuds ansya-a haadzal masjid al-Manar almusamma bil Aqsha khalifatullaahi fil ardli . . . al-'ulyaa wal mujtahid as-sayyid al'Arif al-Kamil al-Fadhil al-Maksus bi-'inaayati . . al-Qodli Ja'far Shodiq . . . sanah sittin wa khomsiina wa tis'i miatin minal hijrah annabawiyyah wa shallallaahu 'alaa sayyidina Muhammadin wa ashhaabihi ajma'iin" (Salam, 1977: 29-30).

["In the name of Allah, the Most Gracious, Most Merciful. Has established the al-Aqsa Mosque and the al-Quds land is a caliph at the time of Muhammad's descendants brought the eternal glory of heaven . . . to draw closer to God in the al-Kuds land, build the mosque of al-Manar (spot light) which is called alAqsa khalifatullaah on earth.

, , , the great and mujtahid Sayyid (master) who Arif (who knows) Kamil (Perfect) Fadhil (in excess of) al-Maksus (reserved), with the maintenance of alQadli (judges) Ja'far Shodiq. , , in the year 956 of hijra prophet Muhammad"].

These inscriptions are still clearly visible above the mihrab of the Mosque AlAqsa that clearly mentioned the number 956 Hijri or Monday Pahing or dated 3 
October 1549 M. That is, according to the conversion conducted by K.H. Turaikhan Adjuhri Es-Syarofi, an expertise on Islamic calendar (Cermin 2005:15).

According to genealogy of Sunan Kudus or Shaykh Ja'far Sadiq, he is the son of R. Usman Haji (who holds Sunan Ngudung in Jipang Panolan) son of King Pastor son of Ibrahim Asmarakandi (Samarkand, Uzbekistan) son of Maulana Muhammad Zaini Jumadilkubra son of Zain Al-Khusain son of Zain Al-Kubra son of Zainul Alim son of Zainul Abidin son of Sayyid Husain son of Fatimah r.a, the wife of Ali and Prophet's daughter. Sunan Kudus then married to Dewi Rukhil, daughter of Raden Makdum Ibrahim, Sunan Bonang, Tuban. Raden Makdum Ibrahim is the son of Raden Rahmat, Sunan Ampel son of Maulana Ibrahim Asmarakandi. Here, the genealogy of Sunan Kudus meets with his wife's nasab lines, he is Maulana Ibrahim Asmarakandi. From his marriage with Dewi Rukhil, Sunan Kudus just get a son of a man named Amir Hasan. Another narration mentions that his marriage with Princess of Pecat Tandaterung of Majapahit, Sunan Kudus have eight sons, they are: Nyi Ageng Pembayun, Panembahan Palembang, Panembahan Mekaos Honggokusumo, Panembahan Kodhi, Panembahan Karimun, Panembahan Joko (died as a child), Queen Pakojo, and Queen Prodobinabar (who later married the Prince Poncowati, the war commander Sunan Kudus) (Salam 1986: 12-13).

Another Muslim touted as the generation before Sunan Kudus was Kiai Telingsing. He (The Ling Sing) is a well-known Chinese painter and sculpturer. Upon his arrival in Kudus, he set up a boarding school and mosque in Nganguk. Another version said that Sunan Kudus was never registered as students in this school. Since his arrival, Kiai Telingsing then lowered descent and an expert in sculpture or in the Java language is called sungging. Furthermore, these offspring form a Chinese community in the southern Muslim Mosque Tower. This area by the people then called Sunggingan which means "the place of the sculpturer" in the southern village of Demangan. Kiai Telingsing also buried in this area (de Graaf and Pigeaud 2001: 111; see also Lombard, 2007: 267-374).

Sunan Kudus stayed in Langgardalem. The name "Langgar" means surau (prayer place), while the "dalem" means king, so Langgardalem can be interpreted as king's prayer place. It is probable that during his lifetime, Sunan Kudus stayed around the Kudus Minaret, as well as the Prophet Muhammad who stayed in the surrounding yard of Mosque Nabawi. In Kudus, Sunan Kudus lived around the place known by the name of Tajug (Salam, 1986:30). Tajug is Sundanese terms to describe small mosques, which in Central Java called "Langgar" and in Minangkabau called "surau". The shape of Tajug that is located arround the Sunan Kudus's tomb remembering us to the shape of paseban that is ordinary located on the palace. In front of Tajug there is building such as gardu (palace security chamber) (see Salam, 1986: 31).

\section{Gusjigang: A Practical Guide for Kudus People}

It can be believed, that the Kudus achieve its prominence based on Sunan Kudus, who died in 1550 AD (Salam, 1986:28). Under his leadership, Kudus became the 
center of Islam with the strong islamic characteristics. However, the face of Muslims in this area looks supple and wrapped with a strong tradition.

There are three traditional ceremonies in Kudus. First, Bedug Dandhang (dhandhangan), the ceremony held around the Minaret ahead of the holy month of Ramadan. Second, Kupatan, the ceremony on the seventh day of Shawwal. On that day, the people go to Bulusan in Ngembal Rejo, the eastern of Kudus. Third, Buka Luwur, the ceremony of changing the cover of the Sunan Kudus tomb. It held every 10th Sura or Muharram in the Islamic calendar. There is a strong influence of Sunan Kudus among the people of Kudus (especially Kudus Kulon) also seen when they build traditional houses. The house should face south, there must nothing in the west, north, or east. It is conducted by reason, it can be seen also in the tomb of Sunan Kudus that also face to the south. Interestingly, despite different traditions and beliefs that are wrapped by rites and cultural traditions, it contains two main elements, such as transmission of knowledge and business activities. Besides known as theologian, Sunan Kudus also known as the guardian of merchants. That's why, the people of Kudus believes that gusjigang as the values taught by the founder of the town. The statement based on the historical fact that the Islamization of Java in the 15th century run through trading activities (Said, http:www.stainkudus.ac.id/beritageneologi-dan-kontekstualisasi-gusjigang-.html; see also http://isknews.com/kudussebagai-kota-santri-saudagar). It was ongoing and underlying a religious character of the Kudus people, as well as an accomplished entrepreneur.

Since the mid-19th century, they have been well-known as a tenacious and successful trader. They were trading to some distant places, including up to Priangan and Malang where they then become a successful trader (de Graaf and Stibbe 1918: 358). In the field of trade, Kudus people were well-known as accomplished intercity traders. They have been used to sell their wares, such as embroidery, clothing, batik, to other cities, especially in Central Java and East Java for days and even weeks. In connection with this activity, often found the settlement of Kudus people outside the Kudus (Cermin 2005: 21). One shopping center in Malang, for example, was known as Kudusan area, and roads that pass in the place was called Kudusan Street. That said, the area was a gathering place for merchants who came from the Kudus. The Kudus traders wandered month to month, then returning to his residence. After approximately half years, they came back to their home. Thus they did repeatedly, and they would not stop do it before they became rich. If they have become wealthy then they were not going to trade again. They just stayed in their very nice house in Kudus (Cermin 2005: 201). The famous of Kudus traders continued until the collapse of the Dutch colonial era. Their expertizes and tenacity in the trading activity could only be rivaled by Bawean and Banjarmasin traders. As we know, Bawean, Kudus, and Banjarmasin was the center for traders in the archipelago (see van Gent et al. 1923: 339 in Budiman 1993: 134). Due to their success in the field of trade, Kudus traders became wealthy and successful traders. They build wonderful houses in their hometown. 
If we look at the figure of Sunan Kudus, apparently gusjigang is not only a doctrine, but also become a practical guide for Kudus people. So that, to be Wong Kudus (the people of Kudus), must be religious and have a superior entrepreneurial spirit. Then, how to interpret gusjigang according to the present context. It is explained as below.

1) Bagus (Goodness). There are two meanings of Bagus. First, it is good in the physical sense, such as good appearance or good looking. Second, good means in the non-physical sense, which is good in deeds and words (good attitude/ akhlakul karimah). In this sense, good can also be understood as being honest. In some events, the honesty must be the main capital. It is only manifested in the form of hearts and deeds. Bagus can also be understood with respect to differences (being tolerance). The attitude that begins to wear off lately.

Based on the magnificent Minaret at Sunan Kudus's tomb, it contains not only a cultural heritage, but also a symbol of harmonious life taught by him. Instead of the building have a new Middle Eastern style, for example, the Sunan actually "built" a minaret with a type of Hindu style. Actually, it is no stranger in the Islamic world. Changes of Hagia Sophia into a mosque in Istanbul Turkey, for example, the face of Islam that is not busy on the things that are exoteric (lahiriah), but on the things that are esoteric (batiniah). The old forms of it, are well maintained, by planting new positive values. The substantive values of Islam (or any religion), entitled to be key important to live in the multicultural society, such as Nusantara/the archipelago.

Minaret, as cultural artifacts shown how Kudus able to harmonize it's people although they have historical background and different cultures, they are Java, Islam, Hinduism, and Chinese. Another interesting example is the ban on the animal slaughter of cattle. Recently, the people believed and still undergo the appeal ban of cow slaughter and replace it with buffalo as part of the continuing values and thoughts of Sunan Kudus. A doctrine that originally emerged from Sunan Kudus conviction to the Hindu beliefs on the sanctity of cattle.

2) Ngaji (Learning). Learning koran derived from Javanese word means Koran (learning). This term used by the Muslim to refer to Islamic religion and learning activities, such as Al-Quran. Recently, in many regions of Kudus there are hundreds of children wearing cap and gloves for men and veils for women carrying the Koran or the yellow book. They flocked to the madrassah or religious schools in Kudus. Koran can also be understood as an attitude and a spirit to always learn, an intellectual characteristic.

However, as an intellectual is not enough. An intellectual or educated people should also enlightened. History proves that Indonesian independence gained by the founding fathers that were not only educated (educated) but also enlightened. Many intellectuals who were only in the "ivory tower" and not grounded. In fact, many intellectuals behave not good, because they are not (yet) enlightened. If we return to the concept of Ngaji, we will see how the teacher-pupil relations not only as the basis of formality (lahir), but also the mind. A "teacher" is not only to teach on science but also they are the inspiration (role model) for their students. Meanwhile, a student 
must be a sincere student. Because the key to open knowledge there on the psyche willing to accept it. For example, Sukarno was so inspired by his teacher, Tjokroaminoto. In the context of entrepreneurship, the Ngaji can also be understood as attitude to always learn and think creatively.

3) Dagang (Entrepreneurship). Indeed, the trading activities can be found also in other towns. However, trading activity in Kudus is very distinctive and cannot be released from Sunan Kudus. Business spirit has led the Kudus people to have a tenacious and independent character. If some, the gentry, for example, assume that trade is an activity that is "bad", then it does not apply to the Kudus people. In fact, through the figure of Sunan Kudus, the business spirit as if getting a strong religious foundation. Therefore, it is not surprising that the trading activity in Kudus also actively conducted by the Sufis (see Mu'tashim and Mulkhan 1998).

Gusjigang is a concept to teach people how to be complete as a human being. A complete human being is to have a good character (behavior), wanted to learn (intellectual), have diligent and superior economic independence (entrepreneurs). Through this additional capital, global competition is no longer a specter to be feared, but the reality must be faced. In the context of the development of indigenous entrepreneurship, gusjigang can be interpreted through three major attitudes such as honest, creative, and tenacious. These three things are main capital for those who eager to win the competition at the global level.

\section{Conclusion}

If gusjigang has been agreed as a community cultural values in Kudus, it should be preserved and must be internalized within in every people. Internalization can also be understood as an effort to live up a value as private property. Berger and Luckmann (1990) said that internalization process is able to be done in two stages, socialization and habituation. Socialization or learning cultural values applied in two forms, primary and secondary. The primary socialization takes place at the family level, child care (learning Qur'an, disciplined exercise of religion, etc.) as a form of knowledge transmission from older to younger generation. Secondary socialization conducted through institutions of formal education (such as universities, schools, and seminaries), non-formal (institutions or study group), or informal (pesantren and langgar).

Therefore socialization requires an intense and attractive relationship between parent and children, moreover it has been associated with "industrialization" context among Kudus people. Can the families still be reliable to transmit values and thoughts of gusjigang, while the intensity of industrial society in family relations tends to decline? This phenomenon can be seen by the emergence of full-day schools and daycares. When family faced the lack of the effective primary socialization media, then this foundation has to be taken over by educational institutions, such as gusjigang as part of their curriculum or teaching materials.

After the values are well-known through the socialization process, it will be a new entry on the next stage, that is habituation. Habituation refers to action based on 
gusjigang's values. The values have been believed to undergo habituation through repeated action and become part of daily life activities. After the process, then gusjigang absorbed belong the people's saint.

\section{Acknowledgement}

This article has been presented in an international event of Muria Cultural Program (MCP) entitled "Developing Local Wisdom Entrepreneurship in the Global Competition" organized by Muria Kudus University (UMK) held on Thursday, 27 October 2016. I shoud delivered a sincere gratitude to Noor Naelil Masruroh that has edited the language.

\section{References}

Berger, Peter L. and Thomas Luckmann. (1990). Tafsir Sosial Atas Kenyataan: Risalah tentang Sosiologi Pengetahuan, translated by Hasan Besari. Jakarta: LP3ES.

Budiman, Amen (1993). Kudus: Sejarah, Masyarakat, dan Kebudayaannya (Semarang: Himpunan Peminat Kebudayaan Semarang.

Cermin (2005). Profil Pesantren Kudus. Kudus: Pemerintah Kabupaten Kudus dan Sentral Riset dan Manajemen Informasi.

de Graaf, H.J., and Th. Pigeaud (2001). Kerajaan Islam Pertama di Jawa: Tinja-uan Sejarah Politik Abad XV dan XVI, translated by Pustaka Utama Grafiti dan KITLV. Grafiti: Jakarta.

de Graaf S. and D.G. Stibbe (1918). Encyclopaedie van Nederlandche-Indie, tweede druk. Leiden: Martinus Nijhoff.

Lombard, D. (2007). “Sekitar Makam Kiai Telingsing di Jawa Tengah". In Ziarah Wali di Dunia Islam. Jakarta: Forum Jakarta-Paris.

Mu'tasim, Radjasa and Abdul Munir Mulkhan (1998). Bisnis Kaum Sufi: Studi Tarekat dalam Masyarakat Industri. Yogyakarta: Pustaka Pelajar.

Mulyana, Slamet. (2005). Negarakertagama dan Tafsir Sejarahnya. Yogyakarta: LkiS.

Olthof, W.L., ed. (1941). Poenika Serat Babad Tanah Djawi Wiwit Saking Nabi Adam Doemoegi Ing Taoen 1647. 's-Gravenhage: M. Nijhoff.

Poesponegoro, Marwati Djoened and Nugroho Notosusanto (1993). Sejarah Nasional Indonesia II. Jakarta: Balai Pustaka.

Prawiroatmojo, S. (1957). Bausastra Jawa-Indonesia, jilid I. Jakarta: Gunung Agung.

Said, Nur (2014) "Geneologi dan Kontekstualisasi Gusjigang: Alnternatif Landasan Pacu Transformasi STAIN menuju "IAIN Sunan Kudus." http://www.stain kudus.ac.id/berita-geneologi-dan-kontekstualisasi-gusjigang-.html. Diakses pada 25 Oktober 2016.

Salam, Solichin (1986). Ja'far Shadiq. Kudus: Menara Kudus.

Salam, Solichin (1977). Kudus Purbakala dalam Perjuangan Islam. Kudus: Menara Kudus.

Salam, Solichin (1995). Kudus Selayang Pandang. Jakarta: Gema Salam.

"Kudus sebagai Kota Santri-Saudagar". http://isknews.com/kudus-sebagai-kotasantri-saudagar, accessed on 25 October 2016). 